\title{
HUBUNGAN ANTARA KECERDASAN EMOSI DENGAN PERILAKU BULLYING
}

\author{
Arif Budi Nugraha, I Wayan Dharmayana, Rita Sinthia \\ Prodi Bimbingan dan Konseling Fakultas Keguruan dan Ilmu Pendidikan \\ Universitas Bengkulu \\ arifbyson94@gmail.com,dharmayana@unib.ac.id, ritasinthia@unib.ac.id
}

\begin{abstract}
ABSTRAK
Penelitian ini bertujuan untuk mengetahui hubungan antara kecerdasan emosi dengan perilaku bullying pada siswa kelas X Tata Boga di SMK Negeri 3 kota Bengkulu. Sampel penelitian berjumlah 64 orang siswa yang diambil dengan teknik simple random sampling dari seluruh kelas X. Penelitian ini adalah penelitian deskriptif kuantitatif dengan teknik korelasi. Instrumen yang digunakan dalam penelitian ini adalah kuesioner kecerdasan emosi dan kuesioner perilaku bullying. Data dianalisis dengan menggunakan korelasi product moment Pearson. Hasil penelitian menunjukkan adanya hubungan negatif yang signifikan antara kecerdasan emosi dengan perilaku bullying dengan $r_{x y}$ sebesar $-0,463$, $(p<0,05)$. Hal ini menunjukkan bahwa terdapat hubungan negatif antara kecerdasan emosi dengan perilaku bullying, artinya semakin tinggi kecerdasan emosi semakin rendah perilaku bullying, dan sebaliknya.
\end{abstract}

Kata kunci : kecerdasan emosi, perilaku bullying

\section{CORRELATION OF EMOTIONAL INTELLIGENCE TO WARD BULLYING BEHAVIOR}

\begin{abstract}
This research aimed to know the correlation of emotional intelligence and bullying behavior of of class ten tata boga at SMK negeri 3 Kota Bengkulu The sample of this research was 64 students. From the whole population of one grade students who were majoring class ten, the sample was taken by conducting random sampling technique. This research was technique descriptive quantitative in analisis correlation. Qustionnaire of emotional intelligence and bullying behavior was used to collected the ardt. The data were analyzed by using correlation of person's product moment. The result showed that there was significant negatif correlation between emotional intelligence and bullying behavior in which $\mathrm{r}$ was about $-0,463$, ( $\mathrm{p}<0,05)$. This revealed that there was negatif correlation between emotional intelligence and bullying behavior towards students. It meant, the highset emotional intelligence the low bullying behavior and in vice versa.
\end{abstract}

Keyword : emotional intelligence, bullying behavior 


\section{Pendahuluan}

Pada era global banyak kejadian yang menyita perhatian para pendidik. Salah satunya adalah adanya tindak kekerasaan di sekolah baik yang dilakukan oleh guru terhadap siswa maupun siswa terhadap siswa lainnya (Afdi, 2017: 2). Adapun kekerasaan yang bersifat menyerang (agresif) dan negatif, telah banyak dilakukan secara berulang kali oleh siswa senior dengan siswa junior hal ini menunjukan adanya ketidak seimbangan kekuatan antara pihak yang terlibat (Olweus dalam Wiyani, 2013: 13).

Hasil observasi pada sekolah SMK Negeri 3 kota Bengkulu terjadi tindak kekerasaan dan penindasan yang terjadi kepada siswa. Peneliti melihat 4 siswa laki-laki sedang berdiri di depan kelas terlihat beberapa di antara siswa menganggu siswi perempuan yang lewat di depan kelasnya, dan mendorong dengan sengaja. Selain itu, terlihat juga mereka melakukan bullying verbal dan memanggil temannya dengan sebutan yang jelek. Siswa junior tidak mampu berbuat apapun selain membentuk kelompok sendiri untuk menghindari penindasaan seniornya. Selanjutnya Perilaku negatif tersebut berupa pemalakan yang dilakukan senior kepada juniornya. Hasil wawancara yang peneliti lakukan kepada beberapa orang siswa SMK Negeri 3 kota Bengkulu menemukan beberapa kasus bullying. Sebagian besar siswa pernah melihat dan menjadi pelaku bullying. Adapun bentuk-bentuk bullying yang pernah terjadi antara lain: membentak, memelototi, memalak, mengejek, dan melakukan pemukulan.

Pentingnya penelitian ini dilakukan dalam layanan bimbingan dan konseling agar dapat memberikan pemahaman tentang perilaku bullying dan kecerdasan emosi salah satu faktor yang mempengaruhinya. Melalui kenyataan di atas penulis tergugah untuk melakukan penelitian dengan judul "Hubungan antara kecerdasan emosi dengan perilaku bullying pada siswa kelas X Tata Boga SMK Negeri 3 Kota Bengkulu”.

\section{Metode Penelitian}

Metode yang digunakan dalam penelitian ini adalah metode deskriptif kuantitatif, dengan teknik korelasi. Teknik korelasi adalah suatu penelitian yang dilakukan dengan mengumpulkan sejumlah data untuk mengetahui serta menentukan ada tidaknya hubungan antara dua variabel atau lebih guna mengukur seberapa besarnya tingkat hubungan kedua variabel yang diukur tersebut (Darmadi, 2014: 206).

Populasi dalam penelitian ini adalah siswa kelas X Tata Boga di SMK Negeri 3 Kota Bengkulu. Jumlah kelas X Tata Boga sebanyak 5 kelas dan jumlah seluruh populasi pada 
penelitian ini adalah 180 siswa. Teknik sampel yang digunakan pada penelitian ini yaitu Simple Random Sampling merupakan sampel yang digunakan secara acak. Sampel penelitian Pada penelitian ini sampel penelitian berjumlah 180 orang yang diambil secara rata dari setiap kelas dalam proporsi tertentu yang berasal dari seluruh kelas X Tata Boga. Dalam hal ini peneliti menggunakan rumus Slovin untuk menentukan ukuran sampelnya.

Teknik pengumpulan data dilakukan dengan menggunakan kuesioner atau angket kecerdasan emosi dan perilaku bullying dengan model Skala Likert yang bertujuan untuk mengetahui hubungan antara kecerdasan emosi dengan perilaku bullying pada siswa kelas $\mathrm{X}$ Tata Boga di SMK Negeri 3 kota Bengkulu.

Uji validitas pada penelitian ini menggunakan bantuan software SPSS versi 16 for windows. Langkah awal adalah menguji validitas butir kuesioner dengan melakukan uji coba kuesioner ke sejumlah responden sampel uji coba yang diduga mempunyai ciri-ciri mirip dengan responden sampel penelitian. Penelitian ini bersifat kuantitatif validitas datanya menggunakan statistik dengan rumus korelasi dari Karl Pearson, peneliti menggunakan rumus korelasi Karl Pearson karena data yang diteliti bersifat kontinum.

Uji reliabilitas pada butir kuesioner perilaku bullying dan kecerdasan emosi ini menggunakan reliability analysis scale (Cronbach's alpha) dengan bantuan program komputer software Statistical Packages for Social Science (SPSS) versi 16 for windows. Peneliti menggunakan reliability analysis scale (Cronbach's alpha) karena rumus Cronbach's alpha lebih cocok digunakan pada kuesioner dengan skor jawaban dalam bentuk gradasi, seperti skala Likert yang menggunakan skor 1,2,3,4. Dari hasil reliabilitas kecerdasan emosi menunjukkan bahwa Alpha Cronbach sebesar 0,936 yang berarti memiliki Alpha Cronbach >0,8 maka data kecerdasan emosi memiliki reliabilitas baik. Begitu juga dengan reliabilitas perilaku bullying menunjukkan bahwa Alpha Cronbach sebesar 0,930 yang berarti memiliki Alpha Cronbach >0,8 maka data perilaku bullying memiliki reliabilitas baik.

Pada penelitian ini uji normalitas dilakukan dengan bantuan software SPSS versi 16 for windows, dengan menggunakan uji normalitas Kolmogorov Smirnov (Sarjono 2013: 53). diperoleh bahwa nilai signifikansi variabel kecerdasan emosi sebesar 0,176 dengan $\mathrm{p}>0,05$ sedangkan variabel perilaku bullying sebesar 0, 248 dengan $\mathrm{p}>0,05$. Hasil tersebut data pada variabel kecerdasan emosi dan perilaku bullying bersifat normal. diperoleh bahwa nilai $\mathrm{F}$ 
linier sebesar 17.732 dengan $\mathrm{p}=0,000 \quad(<0,05)$ yang berarti hubungan antara variabel kecerdasan emosi dengan perilaku bullying adalah linier.

Berdasarkan hasil uji normalitas, data berdistribusi normal, serta linier, maka memenuhi syarat untuk uji hipotesis menggunakan korelasi product Moment. Hal ini menunjukkan bahwa terdapat hubungan negatif yang kuat antara kecerdasan emosi dengan perilaku bullying karena nilai koefisien korelasinya yang mendekati -1. Tingkat signifikansinya sebesar $0.000(\mathrm{p}<0,05)$. Artinya semakin tinggi kecerdasan emosi maka akan semakin rendah perilaku bullying. Sebaliknya, semakin rendah kecerdasan emosi semakin tinggi perilaku bullying.

\section{Hasil dan Pembahasan}

Untuk melakukan pengujian analisis data peneliti terlebih dahulu mengkategorisasikan variabel antara perilaku bullying dan kecerdasan emosi dengan kuesioner perilaku bullying yang terdiri atas 34 item dengan 4 pilihan jawaban yang bergerak dari 1 sampai 4 , sehingga diperoleh rentang minimum adalah 34 maximum adalah 136.

Tabel 1 Kategorisasi data perilaku bullying

\begin{tabular}{cccc}
\hline Kategori & Rentang Skor & Frekuensi & Persentase (\%) \\
\hline Rendah & $34-68$ & 40 & $64,5 \%$ \\
\hline Sedang & $69-102$ & 22 & $34,37 \%$ \\
\hline Tinggi & $103-136$ & 2 & $3,12 \%$ \\
\hline
\end{tabular}

Berdasarkan Tabel 1 dapat dilihat bahwa subjek yang memiliki perilaku bullying rendah sebanyak 40 orang (62,5\%), subjek yang memiliki perilaku bullying sedang sebanyak 22 orang $(34,37 \%)$, dan subjek yang memiliki perilaku bullying tinggi sebanyak 2 orang $(3,12 \%)$.

Kuesioner kecerdasan emosi yang terdiri atas 32 item dengan 4 pilihan jawaban yang bergerak dari 1 sampai 4 diperoleh rentang minium adalah 32 maxsimumnya 128.

Tabel 2 Kategorisasi Data Kecerdasan Emosi

\begin{tabular}{cccc}
\hline Kategori & Rentang Skor & Frekuensi & Persentase (\%) \\
\hline Rendah & $32-64$ & 2 & $3.12 \%$ \\
\hline Sedang & $65-96$ & 13 & $20,31 \%$ \\
\hline Tinggi & $97-128$ & 49 & $76,56 \%$ \\
\hline
\end{tabular}


Berdasarkan Tabel 2 dapat dilihat bahwa subjek yang memiliki kecerdasan emosi rendah sebanyak 2 orang $(3,12 \%)$, subjek yang memiliki kecerdasan emosi sedang sebanyak 13 orang $(20,31 \%)$, dan subjek yang memiliki kecerdasan emosi tinggi sebanyak 49 orang $(76,56 \%)$.

Berdasarkan hasil analisis dan kategorisasi data pada variabel perilaku bullying siswa kelas X Tata Boga di SMK Negeri 3 Kota Bengkulu, tingkat perilaku bullying bervariasi. Ada yang tergolong tinggi, sedang dan rendah. Namun, secara keseluruhan paling banyak tingkat perilaku bullying siswa berada pada kategori rendah. Adanya variasi kategori perilaku bullying pada siswa dipengaruhi oleh kecerdasan emosi siswa yang juga bervariasi. Kecenderungan variasi dalam kategorisasi dapat juga dipengaruhi oleh faktor dari dalam diri siswa itu sendiri, di antaranya kecerdasan emosi. Individu yang memiliki kecerdasan emosi yang tinggi dapat mengendalikan diri dan bertahan dalam menghadapi suatu keadaan yang tidak menyenangkan bagi dirinya sehingga mampu mencurahkan segala kekuatannya sehingga tidak melakukan tindakan bullying. Sebaliknya, jika kecerdasan emosi yang dimiliki tersebut rendah, maka siswa cenderung melakukan tindakan bullying, sehingga terjadilah perilaku bullying (Basyirudin, 2010: 109). Hasil Penelitian menunjukkan perilaku bullying di sekolah SMK Negeri 3 Kota Bengkulu tergolong rendah. Hal ini menunjukkan kecerdasan emosi yang dimiliki siswa cenderung tinggi sehingga tidak melakukan perilaku bullying. Semakin tinggi kecerdasan emosi siswa semakin rendah perilaku bullying. Sebaliknya semakin rendah kecerdasan emosi semakin tinggi perilaku bullying.

Kategori tingkat perilaku bullying yang berbeda-beda ini tergantung dengan jenisnya. Menurut Putri (2016: 20), ada 3 karakteristik seseorang dalam melakukan perilaku bullying yaitu: (1) pelaku bullying hidup berkelompok dan menguasi kehidupan sosial siswa di sekolah, (2) pelaku bullying selalu menampatkan diri di tempat tertentu sekolah, dan (3) pelaku bullying merupakan siswa yang populer di sekolah. Beberapa siswa melakukan perilaku bullying karena merupakan siswa yang menguasi kehidupan sosial di sekolah dan siswa yang populer, sehingga pelaku bullying yang memiliki fisik kuat dan mental tinggi dapat dengan mudah melakukan tindakan kepada korban bullying yang memiliki fisik lemah.

Berdasarkan hasil analisis dan kategorisasi data pada variabel kecerdasan emosi siswa kelas X Tata Boga di SMK Negeri 3 Kota Bengkulu, tingkat kecerdasan emosi siswa kelas X Tata Boga di SMK Negeri 3 Kota Bengkulu bervariasi. Ada yang tergolong tinggi, ada yang 
sedang dan ada yang rendah. Namun, secara keseluruhan paling banyak tingkat kecerdasan emosi siswa berada pada kategori tinggi.

Variasi pada tingkat kecerdasan emosi siswa tersebut karena oleh kemampuan diri setiap individu yang berbeda. Setiap individu memiliki kecerdasan emosi yang berbeda-beda sesuai dengan kemampuan dirinya. Siswa yang kecerdasan emosi tinggi cenderung tidak melakukan tindakan bullying kepada temannya. Sebaliknya siswa yang kecerdasan emosi rendah, cenderung melakukan tindakan bullying. Hal ini sesuai dengan temuan penelitian yang dilakukan oleh Basyirudin (2010: 67) bahwa terdapat perbedaan yang signifikan antara kecerdasan emosi siswa dalam melakukan perilaku bullying tinggi dan siswa yang melakukan perilaku bullying rendah. Siswa yang memiliki kecerdasan emosi tinggi secara umum rendah dalam melakukan tindakan bullying. Sedangkan siswa yang memiliki kecerdasan emosi rendah, cenderung tinggi dalam melakukan tindakan bullying. Hasil penelitian yang dilakukan di SMK Negeri 3 Kota Bengkulu menunjukkan kecerdasan emosi yang dimiliki siswa tinggi, sehingga siswa tidak melakukan tindakan bullying. Semakin tinggi kecerdasan emosi siswa semakin rendah perilaku bullying. Sebaliknya semakin rendah kecerdasan emosi semakin tinggi perilaku bullyingnya.

Hasil pengujian hipotesis penelitian diperoleh hasil bahwa kecerdasan emosi memiliki hubungan negatif yang signifikan dengan perilaku bullying. Hal ini menunjukkan bahwa seseorang yang memiliki kecerdasan emosi rendah maka cenderung melakukan perilaku bullying, dan seseorang yang memiliki kecerdasan emosi tinggi menunjukkan perilaku bullying rendah. Pernyataan tersebut sesuai dengan pendapat Argiati dalam Afriana (2013: 22) yang menyatakan bahwa salah satu alasan seseorang melakukan perilaku bullying karena kurangnya kecerdasan emosi dapat mempengaruhi proses berpikir dalam memutuskan suatu tindakan benar atau salah. Sebagai contohnya adalah seseorang siswa yang kuat, populer, dan menguasai situasi sekolah.

Hasil penelitian ini sesuai dengan hipotesis awal yang menyatakan bahwa terdapat hubungan antara kecerdasan emosi dengan perilaku bullying. Perilaku bullying dipengaruhi oleh kecerdasan emosi yang dimilikinya. Hal ini didasari oleh hasil temuan penelitian yang menunjukkan adanya korelasi yang kuat antara kecerdasan emosi dan perilaku bullying. Koefisien korelasinya, yaitu $-0,463$. Jika dilihat dari nilai $\mathrm{R}^{2}$, kecerdasan emosi dapat mempengaruhi perilaku bullying sebesar 46,3\% dan 57,3\% lainnya dipengaruhi oleh variabel lain. Artinya faktor kecerdasan emosi tergolong tinggi dalam mempengaruhi perilaku 
bullying siswa kelas X Tata Boga di SMK Negeri 3 Kota Bengkulu. Hal ini dibuktikan dengan jawaban kuesioner kecerdasan emosi maupun perilaku bullying yang telah diisi oleh siswa dan hasilnya dilaporkan bahwa jika skor kuesioner perilaku bullying rendah, maka skor kuesioner kecerdasan emosi tinggi. Jika skor kuesioner perilaku bullying tinggi maka skor kecerdasan emosi rendah. Seperti hasil kuesioner yang telah diisi oleh salah satu siswa dengan inisial WCK yang menunjukkan bahwa skor perilaku bullyingnya tergolong tinggi, sedangkan skor kecerdasan emosi tergolong rendah. Selain itu hasil kuesioner siswa dengan inisial MZ, menunjukkan bahwa skor perilaku bullyingnya rendah dan skor kecerdasan emosinya tinggi.

Secara teoritis hasil penelitian ini dapat dijelaskan berdasarkan tahapan-tahapan yang terdapat dalam kecerdasan emosi, yaitu: mengenali emosi, mengelola emosi, motivasi diri, mengenali emosi orang lain, membina hubungan (Goleman dalam Yunani, 2010: 30) Sehingga kecenderungan untuk melakukan perilaku bullying akan berkurang dengan adanya kecerdasan emosi yang dimiliki seorang individu.

Hasil penelitian Yuniarti (2009: 50), melaporkan bahwa terdapat hubungan yang negatif antara pola asuh dan tipe kepribadian dengan perilaku bullying. Artinya, jika siswa memiliki kepribadian baik untuk tidak melakukan perilaku bullying, maka siswa tersebut akan yakin untuk tidak melakukan tindakan bullying. Sebaliknya, jika siswa tidak memiliki kepribadian yang baik, maka mereka cenderung melakukan perilaku bullying.

Salah satu penyebab hal tersebut adalah untuk mencari popularitas, melanjutkan tradisi untuk menunjukkan kekuasaan. Hal ini berasal dari kurangnya kecerdasan emosi yang dimiliki. Kurangnya kecerdasan emosi membuat seseorang melakukan perilaku bullying, hal ini dapat membuat trauma korban bullying. Selanjutnya berdampak kepada korban bullying dan mereka cenderung melakukan tindakan bullying. Hal ini didukung hasil penelitian Septriani (2009: 14) yang melaporkan bahwa tindakan bullying berkorelasi negatif dengan harga diri. Artinya semakin tinggi tindakan bullying yang dilakukan, semakin rendah harga diri seseorang. Begitu juga sebaliknya, semakin rendah tindakan bullying, semakin tinggi harga dirinya. Tingginya tindakan bullying tidak lepas dari kecerdasan emosional untuk melakukan perilaku bullying. Hal ini sesuai dengan hasil penelitian yang dilakukan oleh Rahmawati (2013: 28) yang menunjukkan bahwa terdapat hubungan yang negatif antara kecerdasan emosional dengan perilaku bullying. Artinya, semakin tinggi kecerdasan 
emosional semakin rendah perilaku bullying. Selanjutnya semakin rendah kecerdasan emosionalnya maka semakin tinggi perilaku bullyingnya.

Berdasarkan hasil penelitian yang telah dilakukan tersebut dapat disimpulkan bahwa terdapat hubungan yang negatif antara kecerdasan emosi dengan perilaku bullying siswa. Semakin tinggi kecerdasan emosi siswa, semakin rendah pulaperilaku bullyingnya. Demikian sebaliknya, semakin rendah kecerdasan emosi siswa, maka akan semakin tinggi pula perilaku bullyingnya.

\section{Kesimpulan}

Berdasarkan hasil analisis data yang telah dilakukan dapat ditarik kesimpulan bahwa tingkat perilaku bullying siswa kelas X Tata Boga di SMK Negeri 3 Kota Bengkulu tergolong rendah sedangkan tingkat kecerdasan emosi siswa kelas X Tata Boga di SMK Negeri 3 Kota Bengkulu tergolong tinggi, dan terdapat hubungan negatif yang signifikan antara kecerdasan emosi dengan perilaku bullying siswa kelas X Tata Boga di SMK Negeri 3 Kota Bengkulu. Artinya, semakin tinggi kecerdasan emosi maka semakin rendah perilaku bullying siswa. Sebaliknya, semakin rendah kecerdasan emosi, akan semakin tinggi perilaku bullyingnya.

Untuk Penelitian selanjutnya yang tertarik meneliti topik yang sama disarankan memadukan variabel lain yang diduga turut berperan dan mempengaruhi perilaku bullying. Jika peneliti ingin melakukan penelitian lebih dalam, dapat dilakukan dengan metode kualitatif melalui pemberian treatment berupa layanan bimbingan dan konseling diantaranya seperti, layanan Informasi, layanan penguasaan konten, layanan bimbingan kelompok, dan layanan konseling kelompok.

\section{Daftar Pustaka}

Afdi, D H. (2017). Hubungan antara Penalaran Moral dengan Perilaku Bullying Pada Siswa Kelas Xi IPS di SMA 3 Seluma. Skripsi FKIP Bimbingan Konseling Universitas Bengkulu.

Afriana. D. (2013). Upaya Mengurangi perilaku Bullying di Sekolah dengan Menggunakan Layanan Konseling Kelompok. Skripsi FKIP Bimbingan Konseling Universitas islam negeri Yogyakarta

Basyirudin, F. 2010. Hubungan Kecerdasan Emosi dengan Perilaku Bullying para santri Madrasyah Aliyah Pondok Pesantren Ass'adah Serang Banten. Skripsi Fakultas Psikologi Jakarta: Univesitas Islam Negeri Jakarta.

Darmadi, H. (2014). Metode penelitian pendidikan dan sosial. Bandung: Alfabeta

Goleman, D. (2009). Emotional Intelligence. Jakarta: Pustaka Utama. 
Putri, S, F. (2013). Pengaruh Kecerdasan Emosi dan Kepercayaan Diri terhadap Prestasi Belajar Mata Pelajaran Akuntansi Kelas XI IPS SMA Negeri 3 Magelang. Skripsi Fakultas Ekonomi universitas Negeri Semarang.

Rahmawati, R A .(2013). Hubungan antara Kecerdasaan Emosional dan Perilaku Bullying pada siswa-siswi kelas XI Jurusan Administrasi Perkantoran (AP) SMK Negeri 7 Yogyakarta. Skripsi Fakultas Psikologi Universitas Islam Negeri Sunan Kalijaga.

Sarjono. (2013). SPSS VS LISREL : Sebuah Pengantar. Aplikasi untuk Riset. Jakarta : Penerbit Selemba Empat.

Septriani, M A. (2009). Hubungan Tindakan Bullying di Sekolah dengan Self Esteem Siswa. Jurnal Psikologi, Vol.03, No. 02. Universitas Gunadarma Bekasi.

Wiyani, N A. (2013). School Bullying. Yogyakarta: Ar-ruzz Media

Yunani, A. (2010). Pengaruh Kecerdasan Emosi Terhadap Tingkat Pemahaman Akuntansi. Skripsi Fakultas Ekonomi Universitas Diponegoro Semarang.

Yuniarti, F. (2009). Hubungan antara Pola Asuh dan Tipe Kepribadian dengan perilaku Bullying di Sekolah Pada Siswa SMP. Jurnal Ilmu Pendidikan, Vol. 21, No. 01. Universitas Negeri Malang. 